\title{
Effect of pawpaw leaf meal and multi- enzyme supplementation in the diet on performance, digestibility, and oxidative enzyme status of rabbits
}

Olugbenga D. Oloruntola ${ }^{1,2^{*}}$, Simeon O. Ayodele ${ }^{2}$, Samuel A. Adeyeye ${ }^{3}$, Muyiwa H. Ogunsipe ${ }^{4}$, Olajumoke T. Daramola ${ }^{2}$ and Eyanlola S. Ayedun²

\begin{abstract}
Background: This study aimed at determining the effect of pawpaw leaf meal (PLM 26.14\% crude protein [CP] and $16.06 \%$ crude fiber [CF]) and multi-enzyme (m-E: amylase, beta-glucanase, phytase, cellulase, and xylanase, protease) supplementation in diets on performance, nutrient digestibility, and oxidative status of rabbits. Four experimental diets were formulated and designated as diet 1(0\%PLM-m-E), diet 2(0\%PLM + m-E), diet 3(10\%PLM-m-E), and diet 4(10\%PLM + m-E). One hundred and twenty (120), 5-week-old rabbits of cross breed rabbits (Chinchilla $\times$ New-Zealand white) of equal sexes; weighing $738.21 \pm 33 \mathrm{~g}$ were randomly distributed to 4 dietary treatments (30 rabbits/treatment; 3 rabbits/replicate).

Results: Highest weight gain being recorded in rabbits fed diet 4 is similar to the weight gain recorded for rabbits fed diets 2 and 3 but higher $(P<0.05)$ than weight gain of rabbits fed diet 1. Best feed conversion ratio $(F C R)$ recorded in rabbits fed diet 4 was comparable to the FCR of rabbits fed diets 2 and 3 but higher $(P<0.05)$ than FCR of rabbits fed diet 1. Higher CP digestibility recorded in rabbits fed diets 2 and 4 were similar to CP digestibility in rabbits fed diet 3 but higher $(P=0.01)$ than $\mathrm{CP}$ digestibility in rabbits fed with diet 1 . The starch digestibility was higher $(P<0.05)$ in the rabbits fed $\mathrm{m}$-E supplemented diets 2 and 4 . Higher $(P<0.05)$ glutathione peroxidase and superoxide dismutase activities were recorded in rabbits fed with diets 3 and 4 .
\end{abstract}

Conclusion: PLM inclusion and m-E supplementation improved performance, crude protein, and starch digestibility and antioxidant enzyme status of the rabbits.

Keywords: Monogastric herbivores, Growth, Alternative growth promoter, Unconventional feedstuff, Phytogens, Anti-oxidative status

\section{Background}

Rabbit has been identified as an animal with enormous potential because of its unique attributes such as high prolificacy, rapid growth rate, small body size, short generation interval, and encouraging forage utilizing ability (Akinfala, Matanmi, and Aderibigbe, 2003). This has

\footnotetext{
* Correspondence: oloruntoladavid@gmail.com;

olugbenga.oloruntola@aaua.edu.ng

${ }^{1}$ Animal Science Department, Adekunle Ajasin University, Akungba Akoko, Nigeria

${ }^{2}$ Animal Production Unit, Agricultural Technology Department, The Federal Polytechnic, Ado Ekiti, Nigeria

Full list of author information is available at the end of the article
}

caused the increase in growth of rabbit industries in many African countries, and subsequently, the feeding challenges being faced by the rabbit's breeders. This created the need for a search for alternative feed resources that support the normal health and enhances the performance of the rabbits. The aim of livestock farmer is to produce the animal protein in the shortest possible time to meet the demand for animal protein. To achieve this aim, the use of antibiotic growth promoter in livestock production to promote growth by enhancing feed utilization and inhibition of pathogens activities are being considered by the farmers (Akanmu and Adeyemo, 
2012). However, the awareness of possible microbial resistances in farm animals and the eventual antibiotic residue in animal products later formed a major discouragement for the use of antibiotic growth promoter for animal production (Falcao-e-Cuhna et al. 2007). This thereafter fuelled the search for and the use of the alternative to antibiotic growth promoters or complementary medicines to enhance performance, immunomodulation, and general health maintenance in animal production. Herbs of medicinal values are currently in increasing demand as they are being found suitable for the animal with the benefits of low cost and total safety (Dhama et al. 2015). Medicinal plant parts, when incorporated in the rabbit diets, could serve as protein source suitable for replacing in full or part the conventional and expensive protein feedstuff and also as a phytobiotic growth promoter (Oloruntola et al. 2016). Herbs in monogastric diets are known for impacting the metabolism by combating microbial activities and stress (Dhama et al. 2015) through the prevention of pathogens colonization and enhancement of the digestive enzymes production and activities by the phytogenic components of the plants' parts (Dhama et al. 2015; Langhout, 2000). Numerous plants possess anti-microbial traits which are synthesized during secondary metabolism of the plant (Rusenova and Parvanov, 2009).

Pawpaw (Carica papaya), a plant native to tropical America is popular in the tropics and subtropics. Pawpaw leaves contain a broad spectrum of phytochemicals such as enzyme (papain), alkaloids, and phenolics (Maisarah, Asmah, and Fauziah, 2014) and the anti-bacterial, anti-viral, anti-inflammatory, wound healing, free radical scavenging, and anti-fungal activities of pawpaw had been reported (Ayoola and Adeyeye, 2010; Lim, 2012). Pawpaw has been identified as a natural antioxidant (Martial-Didier, Hubert, Parfait, and Kablan, 2017), and pawpaw leaves have been tested and found to contain essential ingredients capable of enhancing feed intake, feed utilization and suppression of pathogens' growth (Akanmu and Adeyemo, 2012). Therefore, pawpaw leaf meal inclusion in rabbits' diets could be of health benefits against oxidative stress and several diseases. Feed enzymes change the nutritional profile of feed ingredients; improve the digestibility of diets, increase the performance of the animals (Bedford and Gary, 2010; Bolis, Castrvilli, Rigoni, Tedesco, and Luzi, 1996; Fernandez, Merino, and Carabano, 1996), remove anti-nutritional factors effect and improve nutrient availability (Kiarie, Romero, and Nyachoti, 2013). Improvement in feed conversion ratio and mortality of rabbits whose diet was supplemented with cellulase was reported by Eiben et al. (2004).

Therefore, this work investigated the effect of dietary pawpaw leaf meal and enzyme supplementation and their interactions on performance, carcass, and oxidative status of growing rabbits.

\section{Methods \\ Experimental site, pawpaw leaf collection, and commercial enzyme}

This trial was carried out at the rabbit facility of the Agricultural Technology Department Teaching and Research Farm, The Federal Polytechnic, Ado Ekiti, Nigeria after the right to conduct the research granted by the Research Committee of the Department of Agricultural Technology, The Federal Polytechnic, Ado Ekiti, Nigeria. The climate has average annual rainfall of $1247 \mathrm{~mm}$ and mean temperature of $26.2{ }^{\circ} \mathrm{C}$.

Leaves of pawpaw trees were collected, chopped into smaller pieces, spread lightly to air dry under a shed for 14 days, and thereafter sun-dried for $2 \mathrm{~h}$ prior to milling with 2-mm-screen hammer mill. Pawpaw leaf meal was analyzed for proximate composition (AOAC, 1997), phytate (Preet and Punia, 2000), flavonoid (Bohm and Kocipai-Abyazan, 1994), saponin (Shad, Nawaz, Rehma, and Ikram, 2013), and tannin (Makkar and Goodchild, 1986) (Table 1). The commercial multi-enzyme (m-E) used was produced by Bioproton PTY Limited Brisbane Qld Australia and is composed of alpha-amylase/Bacillus subtilis $(400 \mu / \mathrm{g})$, beta-Glucanase/Trichoderma longibrachiatum $(700 \mu / \mathrm{g})$, phytase/Aspergillus niger $(130 \mu / \mathrm{g})$, cellulase/Trichoderma longibrachiatum $(6000 \mu / \mathrm{g})$, xylanase/Trichoderma longibrachiatum $(10,000 \mu / \mathrm{g})$, and protease/Aspergillus niger $(700 \mu / \mathrm{g})$.

\section{Experimental diets and animals}

Four (4) experimental diets were formulated and designated as diet $1(0 \% P L M-m-E)$, diet $2(0 \% P L M+m-E)$, diet $3(10 \%$ PLM-m-E), and diet 4(10\%PLM + m-E). Diets 1 and 3 had PLM inclusion at 0 and 10\% level, respectively; while diets 2 and 4 were enzyme supplemented $(0.5 \mathrm{~g} / \mathrm{kg}$ diet $)$ and had PLM inclusion at 0 and $10 \%$ level, respectively. These four experimental diets were pelletized ( $4 \mathrm{~mm}$ diameter and $8 \mathrm{~mm}$ long) and analyzed

\begin{tabular}{ll} 
Table 1 Chemical composition (\% DM) of pawpaw leaf meal \\
\hline Parameters & Quantity (\%) \\
\hline Crude protein & 26.14 \\
Ash & 16.44 \\
Crude fiber & 16.05 \\
Ether extract & 5.40 \\
Energy (MJ/100 g) & 1135.98 \\
Phytate & 2.03 \\
Flavonoid & 6.21 \\
Saponin & 1.98 \\
Tannin & 0.001 \\
\hline
\end{tabular}


(Table 2). The recommendations and guidelines for applied nutrition experiments in rabbits were followed in the management of the experimental rabbits (Fernández-Carmona et al. 2005). One hundred and twenty (120) healthy, 5-week-old rabbits of crossbreed (Chinchilla $\mathrm{x}$ New Zealand white) of equal sexes; weighing $738.21 \pm 32 \mathrm{~g}$ were distributed to four dietary treatments (30 rabbits/treatment; 3 rabbits/replicate) on random basis and housed in galvanized wire meshed individual cages $(75 \times 60 \times 40 \mathrm{~cm} ; 3$ rabbits per cage $)$ kept in a well-ventilated pen. The rabbits were fed ad libitum throughout the period of the experiment (56 days).

\section{Experimental procedures}

Body weight and feed intake were determined and recorded on a weekly and daily basis, respectively, while the mortality rate was recorded daily. The individual

Table 2 Composition (\%) of the experimental diets

\begin{tabular}{|c|c|c|c|c|}
\hline & $\begin{array}{l}\text { Diet } 1 \\
\text { (O\%PLM-E) }\end{array}$ & $\begin{array}{l}\text { Diet } 2 \\
(0 \% P L M+E)\end{array}$ & $\begin{array}{l}\text { Diet } 3 \\
\text { (10\%PLM-E) }\end{array}$ & $\begin{array}{l}\text { Diet } 4 \\
(10 \% \mathrm{PLM}+\mathrm{E})\end{array}$ \\
\hline Maize & 36.5 & 36.5 & 31.45 & 31.45 \\
\hline Maize husk & 24.00 & 24.00 & 22.00 & 22.00 \\
\hline Soya bean meal & 17.84 & 17.84 & 13.84 & 13.84 \\
\hline PLM & 0.00 & 0.00 & 10.00 & 10.00 \\
\hline Multi-enzyme & 0.00 & 0.05 & 0.00 & 0.05 \\
\hline Wheat offals & 13.91 & 13.86 & 14.46 & 14.41 \\
\hline Rice bran & 5.40 & 5.40 & 5.40 & 5.40 \\
\hline Bone & 1.00 & 1.00 & 1.00 & 1.00 \\
\hline *Premix & 0.25 & 0.25 & 0.25 & 0.25 \\
\hline Methionine & 0.2 & 0.2 & 0.2 & 0.2 \\
\hline Lysine & 0.15 & 0.15 & 0.15 & 0.15 \\
\hline Vegetable oil & 0.5 & 0.5 & 1.00 & 1.00 \\
\hline Salt & 0.25 & 0.25 & 0.25 & 0.25 \\
\hline
\end{tabular}

Determined analysis (\%)

\begin{tabular}{lllll} 
Dry matter & 91.42 & 91.23 & 91.07 & 91.02 \\
Crude protein & 15.01 & 15.03 & 15.02 & 15.04 \\
Ash & 7.33 & 7.39 & 7.42 & 7.39 \\
Crude fat & 3.27 & 3.31 & 3.22 & 3.19 \\
NDF & 38.43 & 38.18 & 38.96 & 39.11 \\
ADF & 17.89 & 17.92 & 18.15 & 18.12 \\
ADL & 4.32 & 4.35 & 4.23 & 4.21 \\
GE (MJ/kg) & 15.63 & 15.61 & 15.59 & 15.60 \\
\hline
\end{tabular}

PLM pawpaw leaf meal, $E$ multi-enzyme, NDF neutral detergent fiber, $A D F$ acid detergent fiber, $A D L$ acid detergent lignin, $G E$ gross energy

*Provided per kg diet: Vitamins A $(8,500,000$ IU); D3 (1,500,000 IU); E $(10,000 \mathrm{mg}) ; \mathrm{K} 3(1500 \mathrm{mg}) ; \mathrm{B} 1$ (1600 mg); B2 (4000 mg); B $(1500 \mathrm{mg}) ; \mathrm{B} 12$ (10 mg); Niacin (20,000 mg); Pantothenic acid (5000 mg); Folic acid (500 mg); Biotin H2 (750 mg); Choline chloride (175,000 mg); Cobalt (200 mg); Copper (3000 mg); lodine (1000 mg); Iron (20,000 mg); Manganese (40,000 mg); Selenium (200 mg); Zinc (30,000 mg); and Antioxidant (1250 mg) per $2.5 \mathrm{~kg}$ daily weight gain and feed conversion ratio (ratio of feed intake to weight gain) were thereafter calculated. Nutrient digestibility was carried out using European reference method for in vivo determination of diet digestibility in rabbits (Perez et al. 1995). Ten 42-day and 6-week-old rabbits were randomly selected from each experimental group ( $1 /$ replicate), placed in individual wire meshed cages $(55 \times 40 \times 30 \mathrm{~cm})$ and fed their respective experimental diets ad libitum. After 7-day adaptation period was a 4-day collection period (day 49 to 53 of age) during which feed intake was determined and total fecal output from each rabbit were collected. The feces were collected using a nylon net fixed under each cage of the selected rabbits at approximately 08:00 $\mathrm{h}$ each morning prior to feeding. The total fecal output was collected in the same individual/labeled polythene bag and stored in the freezer $\left(-18{ }^{\circ} \mathrm{C}\right)$. Dried feed and feces were ground and analyzed for proximate composition, i.e., dry matter (DM; 930.15), CP (N; 954.01), ether extract (EE; 920.39) and crude fiber (CF; 962.09) according to AOAC (1997), neutral detergent fiber (NDF), and acid detergent fiber (ADF) according to Van Soest, Robertson, and Lewis (1991). On day 91 of age, 20 rabbits were randomly selected from each treatment and bled as described by Burnett et al. (2003). About $3 \mathrm{ml}$ of blood samples were collected into the plain tube, centrifuged at $2500 \mathrm{rpm}$ for $10 \mathrm{~min}$. The serum was thereafter extracted, placed in separate tubes, refrigerated at $4{ }^{\circ} \mathrm{C}$, and analyzed for catalase activity (Aebi, 1974), dismutase activity (Misra and Fridovich, 1972), and serum glutathione peroxidase level (Rotruk et al. 1973). At the end of the feeding trial (56 days), rabbits were selected (1rabbit/replicate; 10rabbits/treatment), starved overnight, weighed, tagged, stunned, and slaughtered (Blasco, Ouhayou, and Masoero, 1993). Live weight, commercial skin weight, full gastrointestinal tract weight, hot carcass weight, thymus, trachea, esophagus, lungs, and heart weight were determined as described by Blasco et al. (1993).

\section{Statistical analysis}

Statistical analyses were performed using Statistical Package for Social Sciences, version 20 (SPSS, 2011). Effect of pawpaw leaf meal and enzyme was analyzed using the following general linear model (GLM): $Y_{i j k}=\mu+P_{i}+E_{j}+e_{i j k}$.

Where $\mu$ mean, $P_{i}=$ effect of PLM, $E_{j}=$ effect of $E$, $e_{i j k}=$ random error. The significant difference was tested using the test significant difference post hoc test. The statistical significance was assessed at $(P<0.05)$. Comparison of the diets was analyzed using one-factor analysis of variance (ANOVA), and the differences between diets' means were determined by Duncan multiple range tests (Duncan, 1955). 
Table 3 Effect of enzyme s (E) and dietary pawpaw leaf meal (PLM) on performance of rabbits from 35 to 91 days of age

\begin{tabular}{|c|c|c|c|c|c|c|c|c|c|c|}
\hline & \multicolumn{4}{|c|}{ Experimental diets } & \multirow[t]{2}{*}{ SEM } & \multirow[t]{2}{*}{$P$} & \multicolumn{2}{|l|}{ PLM } & \multicolumn{2}{|l|}{ E } \\
\hline & $\begin{array}{l}\text { OPLM-E } \\
\text { (diet 1) }\end{array}$ & $\begin{array}{l}\mathrm{OPLM}+\mathrm{E} \\
\text { (diet 2) }\end{array}$ & $\begin{array}{l}\text { 10PLM-E } \\
\text { (diet 3) }\end{array}$ & $\begin{array}{l}10 P L M+E \\
\text { (diet 4) }\end{array}$ & & & SEM & $P$ & SEM & $P$ \\
\hline ILW (35 days), g & 736.73 & 745.40 & 733.43 & 737.26 & 31.58 & 1.00 & 52.32 & 0.94 & 52.32 & 0.93 \\
\hline FLW (91 days) g & 2009.40 & 2295.90 & 2301.47 & 2541.73 & 89.34 & 0.22 & 113.70 & 0.13 & 113.70 & 0.13 \\
\hline Weight gain, g/d & $22.72^{\mathrm{b}}$ & $27.68^{\mathrm{ab}}$ & $28.00^{\mathrm{ab}}$ & $32.23^{\mathrm{a}}$ & 1.32 & 0.05 & 1.37 & 0.03 & 1.37 & 0.04 \\
\hline Feed intake, g/d & 48.87 & 49.56 & 46.89 & 46.52 & 1.02 & 0.72 & 1.58 & 0.29 & 1.58 & 0.94 \\
\hline FCR & $2.22^{\mathrm{a}}$ & $1.78^{\mathrm{ab}}$ & $1.69^{\mathrm{ab}}$ & $1.44^{\mathrm{b}}$ & 0.11 & 0.05 & 0.11 & 0.02 & 0.11 & 0.07 \\
\hline Mortality (\%) & 1.00 & 0.66 & 0.66 & 0.66 & 0.13 & 0.80 & 0.20 & 0.58 & 0.20 & 0.58 \\
\hline
\end{tabular}

Means with different superscripts in the same row are significant $(P<0.05)$

ILW initial live weight, FLW final live weight, FCR feed conversion ratio

\section{Results}

The effect of multi-enzyme supplementation (m-E) and dietary pawpaw leaf meal (PLM) on the performance of rabbits from 35 to 91 day of age is presented in Table 3. There exist difference $(P<0.05)$ in the weight gain $(\mathrm{g} / \mathrm{d})$ of the rabbits fed the experimental diets between 35 and 91 day of age, such that highest weight gain $(\mathrm{g} / \mathrm{d}) \mathrm{re}-$ corded in rabbits fed on 10\%PLM inclusive and enzyme supplemented diet 4 , was similar to weight gain of those fed on diets $2(0 \% \mathrm{PLM}+\mathrm{m}-\mathrm{E})$ and $3(10 \% \mathrm{PLM}-\mathrm{m}-\mathrm{E})$ but higher $(P<0.05)$ than the weight gain of those rabbits fed on diet 1 (0\%PLM-m-E). Furthermore, the dietary $10 \%$ PLM and $\mathrm{m}$-E supplementation contributed significantly $(P=0.05 ; P=0.03)$ to the weight gain $(\mathrm{g} / \mathrm{d})$ of the rabbits. Rabbits fed with diet 4 (10\%PLM + m-E) comparably converted their feeds as those fed diets 2 $(0 \% \mathrm{PLM}+\mathrm{m}-\mathrm{E})$ and $3\left({ }^{\prime} 10 \% \mathrm{PLM}-\mathrm{m}-\mathrm{E}\right)$ but significantly $(P<0.05)$ better when compared to those fed diet $1(0 \%$ PLM-m-E). In addition, the FCR was significantly $(P=0.05)$ improved by dietary $10 \%$ PLM and tend to improve $(P=0.07) \mathrm{m}$-E supplementation (Table 3$)$.

The apparent digestibility of crude protein $(\mathrm{CP})$ and starch was affected $(P<0.05)$ by dietary m-E (Table 4$)$. Higher CP digestibility recorded in rabbits fed diets 2
$(0 \% \mathrm{PLM}+\mathrm{m}-\mathrm{E})$ and $4(10 \mathrm{PLM}+\mathrm{m}-\mathrm{E})$ were similar to $\mathrm{CP}$ digestibility of rabbits fed diet 3(10\%PLM-m-E) but higher $(P=0.01)$ than $\mathrm{CP}$ digestibility in rabbits fed with diet 1(0\%PLM-m-E). The dietary 10\%PLM tended $(P=0.06)$ to improve $\mathrm{CP}$ digestibility while $\mathrm{E}$ supplementation significantly increased $(P<0.05) \mathrm{CP}$ digestibility across the diets. The starch digestibility was higher $(P<0.05)$ in the $\mathrm{E}$ supplemented diets 2 and 4 (0\%PLM $+\mathrm{m}-\mathrm{E}$ and $10 \% \mathrm{PLM}+\mathrm{m}-\mathrm{E})$. It was also observed that $\mathrm{E}$ supplementation influenced $(P=0.01)$ the digestibility of starch.

All the carcass traits were stable across the diets (Table 5). Enzyme supplementation promoted variation $(P<0.05)$ the in full gastrointestinal tract weight (FGTW) and hot carcass weight (HCW) of the experimental rabbits. However, this variation did not translate to a significant change in the experimental diets.

Higher glutathione peroxidase $(\mathrm{GPx})(P<0.05)$ and superoxide dismutase (SOD) $(P=0.01)$ activities were recorded in 10\%PLM inclusive diets (diets 3 and 4 ) and dietary $10 \%$ PLM was significant for increased GPx $(P=0.03)$ and SOD $(P=0.01)$ activity in the rabbits. Dietary $10 \%$ PLM was significant $(P=0.04)$ for catalase $(C A T)$ activity in the experimental rabbits, and this tends $(P=0.09)$

Table 4 Effect of the enzyme (E) and dietary pawpaw leaf meal (PLM) on apparent digestibility (\%) from 49 to 53 days of age

\begin{tabular}{|c|c|c|c|c|c|c|c|c|c|c|}
\hline & \multicolumn{4}{|c|}{ Experimental diets } & \multirow[t]{2}{*}{ SEM } & \multirow[t]{2}{*}{$P$} & \multicolumn{2}{|l|}{ PLM } & \multicolumn{2}{|l|}{$E$} \\
\hline & $\begin{array}{l}\text { OPLM-E } \\
\text { (diet 1) }\end{array}$ & $\begin{array}{l}\mathrm{OPLM}+\mathrm{E} \\
\text { (diet 2) }\end{array}$ & $\begin{array}{l}\text { 10PLM-E } \\
\text { (diet 3) }\end{array}$ & $\begin{array}{l}\text { 10PLM +E } \\
\text { (diet 4) }\end{array}$ & & & $\overline{\text { SEM }}$ & $P$ & SEM & $P$ \\
\hline Dry matter & 65.19 & 63.71 & 65.17 & 64.10 & 0.78 & 0.92 & 1.27 & 0.81 & 1.27 & 0.58 \\
\hline Organic matter & 63.79 & 64.10 & 63.07 & 63.90 & 0.73 & 0.98 & 1.21 & 0.79 & 1.21 & 0.74 \\
\hline Crude protein & $69.44^{b}$ & $75.63^{\mathrm{a}}$ & $73.41^{\mathrm{ab}}$ & $76.85^{\mathrm{a}}$ & 0.99 & 0.01 & 0.87 & 0.06 & 0.87 & 0.01 \\
\hline Crude fiber & 27.68 & 30.92 & 27.19 & 27.32 & 0.81 & 0.35 & 1.11 & 0.22 & 1.11 & 0.31 \\
\hline Ether extract & 72.17 & 70.69 & 72.58 & 70.11 & 1.06 & 0.86 & 1.67 & 0.97 & 1.67 & 0.42 \\
\hline Starch & $70.14^{b}$ & $76.65^{a}$ & $70.92^{b}$ & $76.89^{a}$ & 1.10 & 0.01 & 0.95 & 0.71 & 0.95 & 0.01 \\
\hline NDF & 29.53 & 30.59 & 27.92 & 29.70 & 0.77 & 0.74 & 1.19 & 0.48 & 1.19 & 0.43 \\
\hline ADF & 18.60 & 19.34 & 19.52 & 19.43 & 0.60 & 0.96 & 0.99 & 0.72 & 0.99 & 0.82 \\
\hline
\end{tabular}

Means with different superscripts in the same row are significant $(P<0.05)$

$F I$ feed intake, NDF neutral detergent fiber, $A D F$ acid detergent fiber 
Table 5 Effect of the enzyme (E) and dietary pawpaw leaf meal (PLM) on the carcass of rabbits of 91days of age

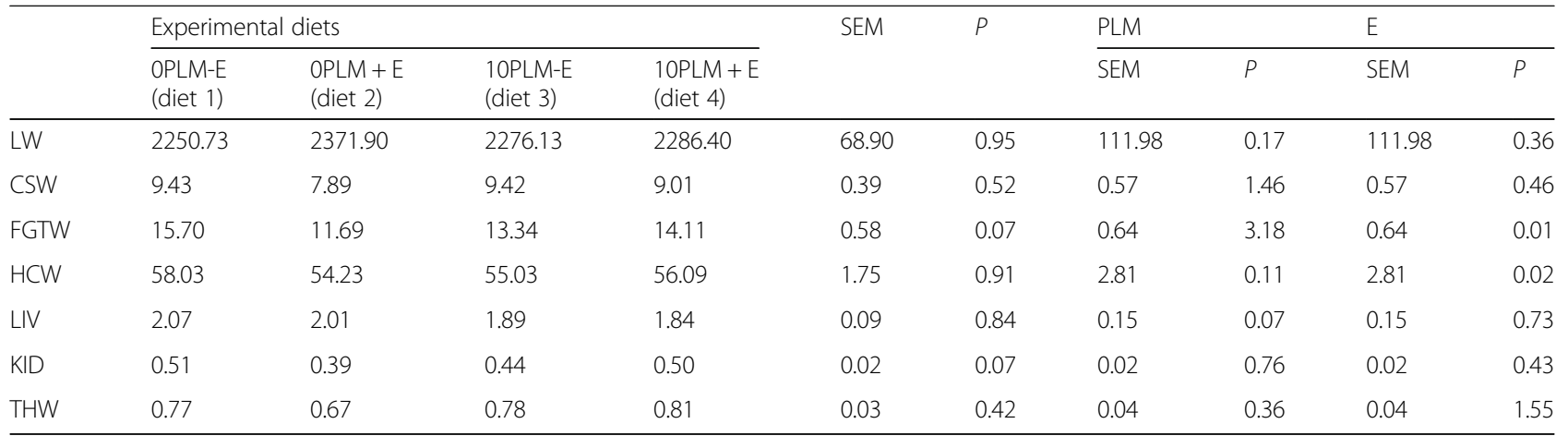

LW live weight (g), CSW commercial skin weight (\% LW), FGTW full gastrointestinal tract weight (\% LW), LIV liver (\% LW), KID kidney (\% LW), HCW hot carcass weight (\% LW), THW thymus, trachea, esophagus, lungs, and heart weight (\% LW)

to cause variation in the CAT activity among the experimental diets (Table 6).

\section{Discussion}

The outstanding performance (daily weight gain and FCR) of rabbits fed the dietary 10\%PLM and E in this study could be associated with the chemical composition of PLM. Papain (a proteolytic enzyme) present in PLM could have aided the digestion of protein, thereby releasing the free amino acids necessary for growth (Onyimonyi and Ernest, 2009). In addition, the phytobiotics properties (Fallah, Kiani, and Azarfar, 2013) of PLM could also play roles in enhancing the performance of the rabbits. For instance, enzyme papain in PLM was reported to have the ability to lyse microorganisms (Adu, Akingboye, and Akinfe, 2009) and some phytochemicals in plants are known for their antimicrobial ability (Cowan, 1999). Therefore, the superior performance recorded by rabbits fed PLM and E inclusive diets in this study might have been caused by maintenance of healthy gut through inhibition of pathogens and reduction of microbial toxic metabolites by the phytochemicals present in PLM. The phytobiotics present in PLM could as well increase the digestive enzyme (trypsin, lipase, amylase, and chymotrypsin) secretion (Fallah et al. 2013; Windisch and Kroismayr, 2006) and probably facilitate the improved nutrient utilization and enhanced performance (Khan et al. 2012). Enzyme supplementation might have also contributed to the improved performance recorded in this study by eliminating or reducing the antinutrient effects and improving the availability of nutrients necessary for growth (Kiarie et al. 2013). The improved performance recorded in this study also agreed with earlier reports that exogenous enzymes are included in rabbit diets to improve nutrient digestibility (Falcao-e-Cuhna et al. 2007), reduce ileal flow and mortality (Gutiérrez, Espinosa, García, Carabaño, and De Blas, 2002a, 2002b), and improve feed conversion ratio (Eiben, Gippert, Godor-Surmann, Podmaniczky, and Kustos, 2008). The performance of the experimental rabbits as being positively affected by the PLM and $\mathrm{m}$-E supplementation in this study agreed with Ayodele, Oloruntola, and Agbede (2016) who reported better FCR in rabbits due to dietary alchornea leaf meal plus multi-enzyme supplementation. The enhanced $\mathrm{CP}$ and starch digestibility recorded in this study is likely to be associated with the activity of the components of the multi-enzyme used in this study. For instance, the phytase, one of the components of the multi-enzyme used in this study could have improved phosphorus utilization (Gutiérrez et al. 2002b) and breakdown the phytate molecule that binds phosphorus and some mineral element in the rabbits' diets (Fuller, 2004). In addition, the multi-enzyme could

Table 6 Effect of the enzyme (E) and dietary pawpaw leaf meal (PLM) on antioxidant enzyme status of rabbits of 91 days of age

\begin{tabular}{|c|c|c|c|c|c|c|c|c|c|c|}
\hline & \multicolumn{4}{|c|}{ Experimental diets } & \multirow[t]{2}{*}{ SEM } & \multirow[t]{2}{*}{$P$} & \multicolumn{2}{|l|}{ PLM } & \multicolumn{2}{|l|}{$E$} \\
\hline & $\begin{array}{l}\text { OPLM- } \\
\text { E } \\
\text { (diet } \\
\text { 1) }\end{array}$ & $\begin{array}{l}\text { OPLM } \\
+\mathrm{E} \\
\text { (diet } \\
\text { 2) }\end{array}$ & $\begin{array}{l}\text { 10PLM- } \\
\text { E } \\
\text { (diet 3) }\end{array}$ & $\begin{array}{l}10 P L M \\
+E \\
(\text { diet 4) }\end{array}$ & & & SEM & $P$ & SEM & $P$ \\
\hline $\mathrm{GPx}(\mu \mathrm{g} / \mathrm{g})$ & $53.37^{\mathrm{b}}$ & $65.12^{\mathrm{ab}}$ & $69.74^{\mathrm{a}}$ & $70.01^{\mathrm{a}}$ & 2.61 & 0.05 & 2.73 & 0.03 & 2.73 & 0.15 \\
\hline SOD (\%) & $55.72^{b}$ & $60.71^{b}$ & $71.77^{\mathrm{a}}$ & $74.31^{\mathrm{a}}$ & 2.52 & 0.01 & 1.69 & 0.01 & 1.69 & 0.16 \\
\hline CAT $(\mathrm{mM} / \mathrm{ml} / \mathrm{min})$ & 6.22 & 8.26 & 9.09 & 10.86 & 0.69 & 0.09 & 0.78 & 0.04 & 0.78 & 0.13 \\
\hline
\end{tabular}

Means with different superscripts in the same row are significant $(P<0.05)$

GPX glutathione peroxidase, SOD superoxide dismutase, CAT catalase 
disrupt the cell wall matrix of fibrous feedstuffs, thereby causing easy access of the endogenous proteolytic and cellulolytic enzymes to digest the entrapped protein and carbohydrate (Asmare, 2014). The result of this study agreed with Ayodele et al. (2016), Fernandez et al. (1996), and Gutiérrez et al. (2002b) who recorded improved CP and crude fiber (CF) digestibility in rabbits by enzyme supplementation. However, crude fiber digestibility was not enhanced by enzyme supplementation in this present study and this was opposite to the earlier reports of Ayodele et al. (2016) and Fernandez et al. (1996).

Abnormal changes in the relative weight of internal organs in animals may be their response to toxins in their feed (Ayodele et al. 2016). In this study, the stability of the various carcass traits across the experimental diets indicates the safety of the experimental diets and similarity in the economic value and quality of the meat products from the rabbits fed the various experimental diets. The improved GPx and SOD activities in 10\%PLM inclusive diets in this study further supports the earlier claim that pawpaw is rich in antioxidant nutrients (Bolu, Sola-Ojo, Olorunsanya, and Idris, 2009) and that active ingredients of plants have strong antioxidant effects such as hydrogen peroxide, nitric oxide, and superoxide neutralization by increasing the production of SOD, GPx, and CAT (Ali, Marrif, Noureldayem, Bakheit, and Blunden, 2006; Dhama et al., 2015). In addition, since oxidative stress was identified as a cause for reduction of growth rate in animals (Vara Prasad Reddy, Thangavel, Leela, and Narayana Raju, 2009); the increased antioxidant enzymes in rabbits fed 10\%PLM inclusive diets in this study may also explain the enhanced performance recorded in the rabbits.

\section{Conclusions}

Dietary 10\%PLM and m-E supplementation improved the performance, crude protein, and starch digestibility in the growing rabbits. Enzyme supplementation reduced the full gastrointestinal tract weight and hot carcass weight of the rabbits. Dietary 10\%PLM improved the antioxidant enzyme status of the rabbits. Dietary $10 \%$ PLM and $\mathrm{m}$-E supplementation may be included in rabbits' diets to improve their performance and antioxidant enzyme status.

\footnotetext{
Abbreviations

ADF: Acid detergent fiber; ADL: Acid detergent lignin; ANOVA: Analysis of variance; CAT: Catalase; CF: Crude fiber; CP: Crude protein; CSW: Commercial skin weight; E: Enzyme; FCR: Feed conversion ratio; FGTW: Full gastrointestinal tract weight; FLW: Final live weight; GE: Gross energy; GPx: Glutathione peroxidase; HCW: Hot carcass weight; ILW: Initial live weight; LW: Live weight; NDF: Neutral detergent fiber; PLM: Pawpaw leaf meal; ROR: Reactive oxygen species; SOD: Superoxide dismutase; THW: Thymus, trachea, esophagus, lungs, and heart weight
}

Funding

This study was not funded by any institution or any other entity.

\section{Availability of data and materials}

The datasets generated and analyzed during the current study are available from the corresponding author on reasonable request.

\section{Authors' contributions}

ODO and SOA suggested the study, participated in its design and coordination. All authors carried out the feeding trial, sample collection, and analysis. ODO and SOA carried out statistical data analysis and interpret the results. ODO, SOA, and $\mathrm{MHO}$ search for literature and prepared the first draft of the manuscript. All authors read and approved the final manuscript.

\section{Ethics approval}

The right to conduct the research granted by the Research Committee of the Department of Agricultural Technology, The Federal Polytechnic, Ado Ekiti, Nigeria. The animals were managed following the recommendation and guidelines for applied nutrition experiments in rabbits.

\section{Competing interests}

The authors declare that they have no competing interests.

\section{Publisher's Note}

Springer Nature remains neutral with regard to jurisdictional claims in published maps and institutional affiliations.

\section{Author details}

${ }^{1}$ Animal Science Department, Adekunle Ajasin University, Akungba Akoko, Nigeria. ${ }^{2}$ Animal Production Unit, Agricultural Technology Department, The Federal Polytechnic, Ado Ekiti, Nigeria. ${ }^{3}$ Animal Health and Production Department, Federal College of Agriculture, Akure, Nigeria. ${ }^{4}$ Animal Production Unit, Department of Agricultural Science, Adeyemi College of Education, Ondo, Nigeria.

Received: 25 February 2018 Accepted: 7 May 2018

Published online: 25 May 2018

\section{References}

Adu, O. A., Akingboye, K. A., \& Akinfe, A. (2009). Potency of pawpaw (Carica papaya) latex as an anthelmintic in poultry production. Botany Research International, 2, 139-142.

Aebi, H. (1974). Catalase estimation. In H. V. Bergmeyer (Ed.), Methods of enzymatic analysis. New York, US: Verlag Chemic, New York Academic Press.

Akanmu, M. A., \& Adeyemo, G. O. (2012). The effect of neem and pawpaw leaves supplementation on blood profile of broilers. International Journal of Current Research, 4(12), 272-276.

Akinfala, E. O., Matanmi, O., \& Aderibigbe, A. O. (2003). Preliminary studies on the response of weaner rabbits to whole cassava plant meal basal diets in the humid tropics. Livestock Research for Rural Development, 15, 4.

Ali, B. H., Marrif, H., Noureldayem, S. A., Bakheit, A. O., \& Blunden, G. (2006). Some biological properties of curcumin: A review. Natural Product Communication, $1,509-521$.

AOAC (1997). Official methods of analysis, (16th ed., ). Washington, DC: Association of Official Analytical Chemists.

Asmare, B. (2014). Effect of common feed enzymes on nutrient utilization of monogastric animals. International Journal of Biotechnology \& Molecular Biology Research, 5(4), 27-34.

Ayodele, S. O., Oloruntola, O. D., \& Agbede, J. O. (2016). Effect of Alchornea cordifolia leaf meal inclusion and enzyme supplementation on performance and digestibility of rabbits. World Rabbit Science, 24, 201-206. https://doi.org/ 10.4995/wrs.2016.3933.

Ayoola, P. B., \& Adeyeye, A. (2010). Phytochemical and nutrient evaluation of Carica papaya (pawpaw) leaves. International Journal of Recent Research and Applied Studies, 5(3), 325-328.

Bedford, M. R., \& Gary, G. P. (2010). Enzymes in farm animal nutrition, (2nd ed.). London: $\mathrm{CAB}, 2010$ International.

Blasco, A., Ouhayou, J., \& Masoero, G. (1993). Harmonization of criteria and terminology in rabbit meat research. World Rabbit Science, 1(1), 3-10. 
Bohm, B. A., \& Kocipai-Abyazan, C. (1994). Flavonoids and condensed tannins from leaves of Hawaiian Vaccicium vaticulatum and V. calycinium. Pacific Science, 48, 458-463.

Bolis, S., Castrvilli, C., Rigoni, M., Tedesco, D., \& Luzi, F. (1996). Effect of enzymes addition in diet on protein and energy utilization in rabbit. In Proc.: 6th world rabbit congress, Toulouse, France, (pp. 111-115).

Bolu, S. A. O., Sola-Ojo, F. E., Olorunsanya, O. A., \& Idris, K. (2009). Effect of graded level of dried pawpaw (Carica papaya) seed on the performance, haematology, serum biochemistry and carcass evaluation of chicken broilers. International Journal of Poultry Science, 8(9), 905-909.

Burnett, N., Mathura, K., Metivier, K. S., Holder, R. B., Brown, G., \& Campbell, M. (2003). An investigation into haematological and serum chemistry parameters of rabbits in Trinidad. World Rabbit Science, 14, 175-187.

Cowan, M. M. (1999). Plant products as antimicrobial agents. Clinical Microbiological Review, 12, 564-582.

Dhama, K., Latheef, S. K., Mani, S., Samad, H. A., Karthik, K., Tiwari, R., ... Tufarelli, V. (2015). Multiple beneficial applications and modes of action of herbs in poultry health and production - a review. International Journal of Pharmacology, 11(3), 152-176.

Duncan, D. B. (1955). Multiple range and multiple F test. Biometrics, 11, 1-42.

Eiben, C. S., Gippert, T., Godor-Surmann, K., Podmaniczky, B., \& Kustos, K. (2008). Effect of dietary phosphorus reduction and phytase supplementation on growth of rabbits. In Proc.: 9th World Rabbit Congress, June 10-13, 2008, Verona, Italy, (p. 201).

Eiben, C. S., Mezes, M., Zijarto, N., Kustos, K., Godor-Surmann, K., \& Erdelyi, M. (2004). Dose-dependent effect of cellulase supplementation on performance of early-weaned rabbit. In Proc.: 8th World Rabbit Congress, Puebla, Mexico, (pp. 799-804).

Falcao-e-Cuhna, L., Castro-Solla, L., Maertens, L., Marounek, M., Pinheiro, V., Freire, J., \& Mourao, J. L. (2007). Alternatives to antibiotic growth promoters in rabbit feeding: a review. World Rabbit Science, 15, 127-140.

Fallah, R., Kiani, A., \& Azarfar, A. (2013). A review of the role of five kinds of alternatives to in-feed antibiotics in broiler production. Journal of Veterinary Medicine and Animal Health, 5(11), 317-321.

Fernandez, C., Merino, J. M., \& Carabano, R. (1996). Effect of enzyme complex supplementation on diet digestibility and growth performance in growing rabbit. In Proc.: 6th World Rabbit Congress, Toulouse, France, (pp. 163-166).

Fernández-Carmona, J., Blas, E., Pascual, J. J., Maertens, L., Gidenne, T., Xiccato, G., \& García, J. (2005). Recommendations and guidelines for applied nutrition experiments in rabbits. World Rabbit Science, 13, 209-228.

Fuller, M. F. (2004). The encyclopedia of farm animal nutrition. Oxfordshire: CABI Publishing.

Gutiérrez, I., Espinosa, A., García, J., Carabaño, R., \& De Blas, J. C. (2002a). Effects of starch and protein sources, heat processing, and exogenous enzymes in starter diets for early-weaned rabbits. Animal Feed Science and Technology, 98, 175-186. https://doi.org/10.1016/S0377-8401(02)00028-7.

Gutiérrez, l., Espinosa, A., García, J., Carabaño, R., \& De Blas, J. C. (2002b). Effect of exogenous phytase on phosphorous and nitrogen digestibility in growingfinishing rabbits. In Proc., 7th World Rabbit Congress. Valencia. Spain, (pp. 277-281).

Khan, R. U., Nikousefat, Z., Tufarelli, V., Naz, S., Javdani, M., \& Laudadio, V. (2012). Garlic (Allium sativum) supplementation in poultry diets: effect on production and physiology. World's Poultry Science Journal, 68, 417-424.

Kiarie, E., Romero, L. F. ., \& Nyachoti, C. M. (2013). The role of added feed enzymes on promoting gut health in swine and poultry. Nutrition Research and Review, 26, 71-88. https://doi.org/10.1017/ S0954422413000048.

Langhout, P. (2000). New additives for broiler chickens. World Poultry, 16, 22-27.

Lim, T. (2012). Edible medicinal and non-medicinal plants, Fruits (vol. 1). New York: Springer Science and Business Media.

Maisarah, A. M., Asmah, R., \& Fauziah, O. (2014). Proximate analysis, antioxidant and antiproliferative activities of different parts of Carica papaya. Journal of Nutrition and Food Science, 4, 2.

Makkar, A. O. S., \& Goodchild, A. V. (1986). Quantification of tannins: laboratory manual, (p. IV+25). Allepo: ICARDA.

Martial-Didier, A. K., Hubert, K. K., Parfait, K. E. J., \& Kablan, T. (2017). Phytochemical properties and proximate composition of papaya (I L. var solo 8) peels. Turkish Journal of Agriculture-Food Science and Technology, 5(6), 676-680.

Misra, H. P., \& Fridovich, I. (1972). The univalent reduction of oxygen by flavins and quinines. Journal of Biological Chemistry, 247(1), 188-192.

Oloruntola, O. D., Ayodele, S. O., Agbede, J. O., Oloruntola, D. A., Ogunsipe, M. H., \& Omoniyi, I. S. (2016). Effect of Alchornea cordifolia leaf meal and enzyme supplementation on growth, haematological, immunostimulatory and serum biochemical response of rabbits. Asian Journal of Biological and Life Sciences, 5(2), 190-195.

Onyimonyi, A. E., \& Ernest, O. (2009). An assessment of pawpaw leaf meal as protein ingredient for finishing broiler. International Journal of Poultry Science, 8(10), 995-998.

Perez, J. M., Lebas, F., Gidenne, T., Maertens, L., Xiccato, G., Parigi-Bini, R., ... Bengala Freire, J. (1995). European reference method for invivo determination of diet digestibility in rabbits. World Rabbit Science, 3(1), 41-43.

Preet, K., \& Punia, D. (2000). Proximate composition, phytic acid, polyphenols and digestibility (in vitro) of four brown cowpea varieties. International Journal of Food Science and Nutrition, 51(3), 189-193.

Rotruk, J. T., Pope, A. L., Ganther, H. E., Hafeman, D. G., Swanson, A. B., \& Hekstra, W. G. (1973). Selenium: Biochemical role as a component of glutathione peroxidase. Science, 179(4073), 588-590. https://doi.org/10.1126/science.179.4073.588.

Rusenova, N., \& Parvanov, P. (2009). Antimicrobial activities of twelve essential oils against microorganisms of veterinary importance. Trakia Journal of Sciences, 27(1), 37-43.

Shad, M. A., Nawaz, H., Rehma, T., \& Ikram, M. (2013). Determination of biochemicals, phytochemicals and antioxidative properties of different part of Cichorium intybus L.: A comparative study. The Journal of Animal and Plant Science, 23(4), 1060-1066.

SPSS. (2011). Statistical Package for Social Scientists. Version 20. www.spss.com.

Van Soest, P. J., Robertson, J. B., \& Lewis, B. A. (1991). Methods for dietary fibre, neutral detergent fibre and nonstarch polysaccharides in relation to animal nutrition. Journal of Dairy Science, 74, 3583-3597. https://doi.org/10.3168/jds. S0022-0302(91)78551-2.

Vara Prasad Reddy, L. S. S., Thangavel, A., Leela, V., \& Narayana Raju, K. V. S. (2009). Antioxidant enzyme status in broilers: Role of dietary supplementation of Tulasi (Ocimum sanctum) and selenium. Tamilnada Journal of Veterinary and Animal Science, 5(6), 251-256.

Windisch, W., \& Kroismayr, A. (2006). The effect of phytobiotics on performance and gut function in monogastrics. http://www.feedindustry.org/feed-articles/ animal-nutrition/effect-of-phytobiotics-on-performance-and-gut-function-inmonogastrics/.

\section{Submit your manuscript to a SpringerOpen ${ }^{\mathcal{O}}$ journal and benefit from:}

- Convenient online submission

- Rigorous peer review

- Open access: articles freely available online

- High visibility within the field

- Retaining the copyright to your article

Submit your next manuscript at $>$ springeropen.com 